\title{
Legal consequences and problems of the servitudes of right of way established by administrative acts in Latvia
}

\author{
J. Dinsberga and K. Bite \\ Rīga Stradiņš University, Riga, Latvia
}

\begin{abstract}
The right to own a property is guaranteed by the Article 105 of the Constitution of the Republic of Latvia that in the same time stipulates that the said rights may be restricted only in accordance with law. This legitimate property right restriction is determined in Article 928 of the Civil Law: the ownership may be restricted both by private intent and by law. One of the restrictions of ownership rights is the servitude of right of way which is established by law, a contract, a court judgement, or a will. During the land reform, the State Forest Service, land commissions, and municipalities had the legal basis to establish the servitude of right of way also by an administrative act, taking a corresponding decision. However, many decisions were insufficient and legally incorrect. As a result, today the servitudes of right of way established by the administrative acts during the period of the land reform do not fulfil their purpose and cause a number of legal and practical problems both to owners of immovable property and to state institutions. In order to explore these problems, referring to the Article 7 of the Paragraph 105 of the protocol resolution No. 56 of the Cabinet of Ministers from 29 October 2013, the Ministry of Environmental Protection and Regional Development in cooperation with the Ministry of Transport, the Ministry of Justice, and the Ministry of Agriculture issued the Conceptual Report "On the Problems Occurring in Relation with the Servitudes of Right of Way Established during the Land Reform and Their Possible Solutions" (hereinafter - the Conceptual Report). In general there are 2 possible solutions, but for the second solution there are five courses of action, one of which - in cases when there is a road on private property that is needed for public use it is to be determined as an encumbrance of the immovable property "Public road". The aim of the research is by analysis of the problems of the servitudes of right of way, established by the administrative acts during the period of the land reform, to evaluate whether the solutions offered in the Conceptual Report are practically applicable and will give the desired result, as well as to offer the author's vision for solution of the existing problems. The author has used the scientific research approaches - descriptive, analytical, inductive and deductive, logical-constructive, formal-dogmatic, graphical and interpretation of legal norms - grammatical, systemic, and teleological.

Key words: servitude of right of way; land reform; public road; property rights.
\end{abstract}




\section{Introduction}

The right to own property is one of the fundamental rights of a human guaranteed by the Protocol No. 1, Article 1 of the Convention for the Protection of Human Rights and Fundamental Freedoms [1, 1], Article 105 of the Constitution of the Republic of Latvia that in the same time stipulates that the property rights are not absolute rights and may be restricted in accordance with law [2, 105]. This type of property right restriction is stipulated in the Civil Law. Article 927 of the Civil Law states "Ownership is the full right of control over property [...]" [3, 1130]. Full right of an owner is expressed as implementation of the right of possession, use and action. However, on basis of Article 928 of the Civil Law "[...] ownership may, pursuant to private volition, as well as pursuant to law, be restricted in various ways $[. .] ".[3,928]$. One of the property right restrictions, causing problems to many owners of immovable property in Latvia, is the servitude of right of way. The essence of the servitude of right of way is revealed by Article 1130 of the Civil Law stating that "servitude is such right in respect of the property of another as restricts ownership rights regarding it, with respect to utilisation, for the benefit of a certain person or a certain parcel of land" $[3,1130]$. The existence of servitude of right of way requires immovable property of a person, utilisation of which is determined for the benefit of another person or another immovable property that has the right to use the servitude of right of way. Thus, when establishing servitude of right of way the immovable property or a particular person for the benefit of which it is established must be precisely determined.

According to Civil Law servitudes shall be established by (1) law; (2) court order; (3) agreement or will. However, during the land reform, commenced in Latvia in 1990, within framework of which property rights of former owners or their heirs were resumed, or the land was granted for use or in property against payment, a range of laws and regulations were drawn up determining that a servitude can be established by state or municipal institutions issuing an administrative act. For example, the Law on Land Privatisation in Rural Areas, the Law on Land use and Land Survey, Regulation on Land in Rural Areas, Regulation on Land in Cities, etc. Above mentioned laws and regulations imply that during the land reform the State Land Service, Land Committees and municipalities had legal basis to establish servitude of right of way also by an administrative act passing a respective decision. A. Grūtups indicates: "The land reform takes place already since 1991, and should we only base on the Civil Law and the municipalities would not have the right to establish servitudes, the prospective owners as from 1991 would only have had two options: to conclude mutual agreements in each case, or, if they are unable to come to an agreement, to apply to a court" $[4,139]$. We can unequivocally agree with the opinion of A. Grūtups, however, we have to emphasize that many decisions of the state and municipal institutions passed during the land reform were imperfect and legally incorrect. For example, the decision stated the servitude property (property encumbered with servitude of right of way) but did not state the dominant property (property the benefit of which the servitude is established for); the servitudes of right of way were not marked in title plans or the decisions were not supplemented with graphical attachments with servitude of right of way; the decisions establishing servitudes did not have particular references as to the width, length, etc. of the servitude of right of way. In the result of what the servitudes of right of way established during the land reform by an administrative act today do not perform their functions and cause a row of problems of legal and practical character both to the owners of the immovable property and the state institutions. In order to survey these problems on basis of Article 7 of the Paragraph 105 of the protocol resolution No. 56 of the Cabinet of Ministers from 29 October 2013, the Ministry of Environmental Protection and Regional Development in cooperation with the Ministry of Transport, the Ministry of Justice, and the Ministry of Agriculture issued the Conceptual Report. Mainly these are cases when there is 
a road on an immovable property that during the land reform has been established as servitude of right of way and that is necessary to provide access to national or municipal roads for one or even several hundreds of immovable properties. However, according to the current legal regulations and observing the principle of protection of a person's property rights there is no legal justification to use this road.

Aim of the research: The aim of the research is by analysis of the problems of the servitudes of right of way, established by the administrative acts during the period of the land reform, to evaluate whether the solutions offered in the Conceptual Report are practically applicable and will give the desired result, as well as to offer the author's vision for solution of the existing problems.

We have to note that in general there are 2 possible solutions in the Conceptual Report, but for the second solution there are five courses of action for solution of problems of the servitudes of right of way established by the administrative acts. The authors have planned to devote a separate article to each of the solutions and courses of action providing deeper analysis. The present article gives detailed analysis of the $2^{\text {nd }}$ solution: Complex courses of action for solution of access problems; course of action: Public road as an encumbrance of immovable property, where the authors of the Conceptual Report offer establishment of a legislative property right restriction - public road, that would ensure use of private roads and national or municipal roads located on private land.

\subsection{Research materials}

The research is mainly based on analysis of the Conceptual Report and the land reform laws, which grant the state institutions the right to establish servitudes of right of way by administrative acts. The authors have studied the legal framework of the current valid Civil Law, as well as the legal framework of servitudes in historical view, analysing establishment of servitudes of right of way in Part III of the Collection of Local Laws that was valid in Latvia (except Latgale) until 1937. As secondary sources the authors have used the Study on Servitudes of Right of Way Established During the Land Reform ordered by the Ministry of Environmental Protection and Regional Development and prepared in 2014 by SIA "A\&O konsultāciju pakalpojumi”, opinions expressed in the legal literature of $\mathrm{M}$. Auders and experts of the civil rights, for example A. Grūtups, J. Rozenfelds, G. Višñakova.

\subsection{Methods}

The following scientific research methods have been used during the research:

Descriptive - study of the legal framework of establishment of servitudes of right of way by administrative acts, gathering of information, provision of explanation and identification of problems on basis of the study. Analytical - study of laws and regulations, case law, opinions of authors to clarify the essence of servitude and the problems of servitudes of right of way established by administrative acts within framework of the studied issue. Inductive and deductive - for expression of separate judgements during the course of study. Logical-constructive - for expression of editions of particular amendments to legal provisions. Formal-dogmatic - for critical evaluation of the valid legal provisions on types of restrictions to immovable property and offering of amendments for their further determination. Graphical - arrangement of information in tables to ease the perception.

The following methods of interpretation of legal provisions have been used during the research:

Grammatical - study of the meaning and nature of concepts "servitude of right of way", "establishment of servitude", "making of a note in the Land Register". Systemic - study of 
the peculiarities of establishment of servitudes of right of way in the laws and regulations passed during the land reform in connection with the legal provisions of the Civil Law for establishment of servitudes of right of way. Teleological - study of the legislator's will when adopting laws and regulations by which the state institutions are granted the right to establish servitudes of right of way by administrative acts; to understand the social aim of it.

\section{Results}

Following the legal and political processes in Latvia in general, development of public and private rights, having analysed former studies, historical and currently valid laws and regulations, assessed opinions of case law and opinions of experts of civil rights regarding improvement, strengthening and modernisation of the legal framework the authors came to a conclusion that one of the most current problems in the area of property rights is connected with the servitudes of right of way established during the land reform. We have to admit that the problems with the servitudes of right of way established by administrative acts was topical more than ten years ago and the author J. Dinsberga studied a part of the problems related to restrictions of property rights arising from servitudes of right of way established during the land reform and provided possible solutions already in 2003 [6, 2003], as well as in 2012 when participating in the scientific conference organised by the Riga Stradiňš University "Topical Issues of Legal Problems Pacta sunt servanda" with the paper "Problems Related to Establishment of Servitude of Right of Way" [7, 2012].

Unfortunately we have to note that the laws and regulations regulating servitudes have almost not been amended since adoption. Moreover, the existing legal framework of servitudes given in the Civil Law is very similar to the legal framework provided in Part III of the Collection of Local Laws. The definition of servitude provided in Article 1089 [8], the list of types of servitudes of right of way in Article 1118 [8], and the list of basis for establishment of servitudes in Article 1250 [8] are practically identical to the current formulations provided in the Civil Law. Regardless the fact that the state and municipal institutions already at the beginning of implementation of the land reform had stated problems with legal registration of servitudes established by administrative acts in the Land Register and practical application thereof, these issues were disregarded for a long time. Therefore the range of unsolved issues related to servitudes increased year by year. The problem issues of abovementioned area became priority on a national level only on 29 October 2013 when the Cabinet of Ministers instructed the Ministry of Environmental Protection and Regional Development in cooperation with the Ministry of Transport, the Ministry of Justice, and the Ministry of Agriculture to draw up the above-mentioned Conceptual Report.

Of course, to speak about urgency of an issue it is not enough with problems and conflicts among several legal entities due to insufficient legal basis. In this case it is necessary to state the fact that problems of similar nature affect interests of a substantial part of legal entities and/or state or municipalities. It is also necessary to evaluate the legal consequences that might be caused if the problem is not solved in long-term. M. Auders [9] has studied servitudes of right of way established during the land reform by administrative acts, and his theses are included in the Conceptual Report [10]. The authors are of positive opinion of the development of the Conceptual Report and problems provided therein, but it has one substantial deficiency - information has been gathered only about one administrative unit of Latvia: Sigulda district, Sigulda Rural Municipality. The report states that: "The largest part of problematic cases today is formed by servitudes of right of way, where the dominant property has not been determined, as well as servitudes of right of way established for the benefit of particular immovable properties; however, without complete 
listing of the dominant properties" [10]. The table below provides information indicating which state institution and in how many cases in the Sigulda Rural Municipality has made a decision to establish servitude of right of way, but the decision fails to provide the dominant property for the benefit of which the servitude of right of way is established.

Table 1. Servitudes established by the Rural Municipality Councils, Land Committees and the State Land Service [10].

\begin{tabular}{|c|c|c|c|c|c|}
\hline \multicolumn{2}{|c|}{$\begin{array}{c}\text { Rural Municipality } \\
\text { Council }\end{array}$} & \multicolumn{2}{c|}{ Land Committee } & \multicolumn{2}{c|}{ State Land Service } \\
\hline $\begin{array}{c}\text { Dominant } \\
\text { immovable } \\
\text { property } \\
\text { has been } \\
\text { provided }\end{array}$ & $\begin{array}{c}\text { Dominant } \\
\text { immovable } \\
\text { property } \\
\text { has not } \\
\text { been } \\
\text { provided }\end{array}$ & $\begin{array}{c}\text { Dominant } \\
\text { immovable } \\
\text { property } \\
\text { has been } \\
\text { provided }\end{array}$ & $\begin{array}{c}\text { Dominant } \\
\text { immovable } \\
\text { property } \\
\text { has not } \\
\text { been } \\
\text { provided }\end{array}$ & $\begin{array}{c}\text { Dominant } \\
\text { immovable } \\
\text { property } \\
\text { has been } \\
\text { provided }\end{array}$ & $\begin{array}{c}\text { Dominant } \\
\text { immovable } \\
\text { property } \\
\text { has not } \\
\text { been } \\
\text { provided }\end{array}$ \\
\hline 3 & $\mathbf{1 5}$ & $\mathbf{3 9}$ & $\mathbf{2 9}$ & $\mathbf{5 2}$ & $\mathbf{1 9}$ \\
\hline
\end{tabular}

The information provided in the table indicates that all decision makers in Sigulda Rural Municipality have made mistake and failed to provide the dominant immovable property according to the Civil Law. Since there are 119 municipalities in Latvia - 110 districts and 9 cities [11, Attachments No. 1 and 2], it would be necessary to survey other administrative units of Latvia and to determine what is the situation and problems related to establishment of servitudes there (the point of view of the authors regarding this issue is provided in more detail in the conclusions of the present article). At the moment, while only the Sigulda Rural Municipality has been studied, it only gives an insight into the essence of the problem, but does not reflect the actual situation in the whole Latvia. Should the decision on solving of the problems related to servitudes of right of way established by administrative acts be based on these insufficient facts, the history might repeat and decisions that are unreasoned and inadequate for the local situation might be passed.

In addition to the mentioned problem when the decision of an institution does not determine the dominant immovable property the Conceptual report lists the following problems:

- "servitudes of right of way established by a decision of a municipality are registered in the Land Register not in the form of a record, but in the form of a note (authors' note - servitude as an encumbrance (rights in Rem) must be recorded in the Land Register section of the servient immovable property as an encumbrance for the benefit of the dominant immovable property. Rights to an immovable property are registered in the form of a record, but securities and restrictions are registered in the form of a note. A note can be replaced by a record, if the owner or a respective interested party submits a request for registration in the Land register). Considering the fact that the dominant property has not been determined, it is impossible to identify the interested person, based on the request for registration of which the note might be replaced by a record. Therefore the rights of users of servitude are not protected [...]; 
- in order to get to the property several neighbouring properties must be encumbered, however, that has not been done and the road is only partly usable (authors' note - neighbouring properties are immovable properties located next to each other and crossed by servitude of right of way. In case at least one of the immovable properties is not encumbered, nobody is entitled to use the road on that property and an interruption of the division of servitude of right of way is formed);

- servitude is established, but the road is used by unlimited number of users or in the event of reorganisation of borders the road connects several roads of higher importance, thus it has become a public road;

- servitude is established, but the road in the National Real Estate Cadastre Information System (hereinafter - NRECIS) is registered as a construction and a municipal property, whereby there is a situation when the land is owned by one person, but the road located on the land is under jurisdiction of another person;

- servitude of right of way or a road marked "public road" is provided only in the title plan, but not in the administrative act. In fact this servitude of right of way is invalid; however, it might be registered in the NRECIS and probably in the Land Register in the form of a note". [12]

In order to find solutions to the particular problems, firs of all we have to state the cause of the problems and the reason of passing incomplete and legally incorrect decisions during the land reform. The Conceptual Report and the "Study on Servitudes of Right of Way Established by Administrative Acts during the Land Reform" do not provide in-depth research of this aspect. Therefore the answer can be found at the beginning of the land reform, when on 13 June 1990 the decision of the Supreme Council of the Republic of Latvia "On Agrarian Reform in the Republic of Latvia" was passed [13, 1990], determining that the government shall implement the land reform and the Council of Ministers was charged with preparation of the necessary laws and regulations. Having selected and evaluated the laws and regulations and amendments thereof passed during the land reform, we can state that the number is impressive and many laws and regulations were passed in the same time and over a rather short period of time. That means these laws and regulations were adopted in a hurry, affecting their quality that is indicated by the numerous amendments to the laws and regulations on the land reform.

Several laws and regulations that contained provisions regarding servitudes were passed before coming into effect of the Rights in Rem part of the Civil Law (1 September 1992) and they did not provide as detailed legal order for the servitudes as that provided in the Civil Law. For example, Article 32 of the "Law on Land Use and Land Survey" stated that "It is prohibited for natural persons and legal entities to use land tenures of other natural persons and legal entities (for walking, driving, movement of animals and other purposes) without agreement with the respective land user, except in cases when granting the land the servitudes related to use of the land have been established. Types of servitudes are determined by the Regulation on Land in Rural Areas and the Regulation on Land in Cities." [14] The Regulation on Land in Rural Areas [15] was passed on 25 November 1991, and several articles of the regulation included provisions regarding servitudes (Articles 1, 11.5; 11.6; 53-57). The legal framework of servitudes in the said regulation was incomplete and might have affected quality of the made decisions. However, also after coming into effect of the Rights in Rem part of the Civil Law a part of officials, when deciding on renewal of property rights or granting of land for use, or in property against payment and applying special laws and regulations did not take into account the special provisions of the Civil Law regarding servitudes. Thus by ignoring the definition of servitudes provided in Article 1130 of the Civil Law and other articles, the decisions did 
not stipulate immovable properties or persons, for the benefit of which servitudes of right of way were established, the location, width, length of servitude of right of way were not provided, the established servitudes were named public servitudes or public roads disregarding the fact that there is no such classification of servitudes in Latvia.

Having assessed the historical situation and the possible factors affecting the decision making, the authors have come to conclusion that the shortcomings of the made decisions before coming into effect of the Rights in Rem part of the Civil Law can be justified by the insufficient legal framework. But the shortcomings allowed after that are to be assessed critically and lack of competence and inability to pass legally correct decisions of the officials systematically applying provisions of the Civil Law and the valid laws and regulations regarding the institute of servitude has to be admitted. Expert of the civil rights G. Višnnakova is of the opinion that when establishing servitude one should strictly base on the Civil Law [16, 140]. Article 1130 of the Civil Law is the general normative document that reveals the essence of servitude, but the special laws and regulations only stipulate in which cases and how servitudes are established.

Today, when drawing up and selecting a problem solution, we have to avoid the former mistakes made by the lawmakers and enforcers, wherewith we offer analysis of the draft protocol resolution of the Cabinet of Ministers and the solution offered in the Conceptual Report providing establishment of an encumbrance of the property rights - public road - to solve the problems caused by servitudes established by administrative acts.

At the moment the Ministry of Environmental Protection and Regional Development has drawn up a protocol decision of the Cabinet of Ministers supporting the solutions provided in the Conceptual Report, and Clause 4 of the protocol resolution states "The Ministry of Justice shall draw up and the Minister of Justice until 31 June 2017 in accordance with the procedure provided in the laws and regulations shall submit to the Cabinet of Ministers for review the draft Regulation "Amendments to the Cabinet of Ministers Regulation No. 305 "Provisions for determination of cadastral Value" of 18 April 2006" and the draft Regulation "Amendments to the Cabinet of Ministers Regulation No. 61 "On Establishment and Maintenance of Encumbered Territory Information System and Classification of Encumbrances of Immovable Property Objects" of 4 February 2014", including a new encumbrance "public road", as well as amendments to the Law on Information System of Encumbered Territories stating that the Information system of encumbered territories shall include information on territories that are encumbered with public roads. [17]. It means that part of the problems will be addressed by introduction of a new legal norm "public road".

Although the servitudes of right of way established during the land reform when passing decisions regarding renewal of property rights or granting of land for use, or in property against payment were marked "public roads" this concept in the laws and regulations did not exist. Also today there is no legal definition of public road in the laws and regulations of Latvia. Nevertheless this concept is mentioned in mandatory regulations of several municipalities. For example, in the section "Applicable Terms" of the Regulations for Territory Use and Construction of the Town of Valdemārpils with its Rural Territory the public road is explained as a road that is in possession of natural persons or legal entities and that is used to access several properties [18]. An identical description is provided in the Territory Planning of Roja District (2011-2023), Regulations for Territory Use and Construction of Roja District 2011 [19, Article 60]. In Clause 5.2.1 of the said regulations the public road is divided together with national motor roads, municipal roads, streets and roads as a separate category of roads determining respective protective zone on basis of intensity of use of the public road. Clause 304 of the Regulations for Territory Use and Construction of Jēkabpils of 4 March 2010 states "New local streets (as well as squares, pedestrian streets, public access roads, engineering communication corridors and separate 
bike lanes) and their red lines are determined in detail planning separating them from territories of other type of use" [20]. Article 1 Paragraph 11 and Article 44 Part eight of the Law on Expropriation of the Public Person Property use the term "public street (road)".

This allows concluding that the concept "public road" does not have an unequivocal description in the laws and regulations of Latvia. It is more used in everyday speech to designate roads that are used by more than one person for walking, driving or access to several properties.

But Sect. 1, Article 3 Paragraph 11 of the Directive 2014/47/EU of the European Parliament and of the Council of 3 April 2014 on the technical roadside inspection of the roadworthiness of commercial vehicles circulating in the Union and repealing Directive 2000/30/EC Text with EEA relevance explains: "public road" means a road that is of general public utility, such as a local, regional or national road, highway, expressway or motorway [22]. The said explanation provides that the term "public road" includes roads of various categories used by public.

In Latvia, according to Article 3 of the Law on Motor Roads [23], motor roads are divided by their importance: national motor roads (main, regional and local); municipal roads; commercial roads; access roads. Access roads and commercial roads usually are in private property and the owners in accordance with Article 5 Part four of the Law on Motor Roads have the right to decide on a prohibition to use the road, restrictions or termination thereof having coordinated that with the local municipality. But the national and municipal roads are for free access to the public. Therefore the authors do not understand, why a separate restriction "public road" should be established, when it will have the same function as the existing national and municipal roads - it will be a road that can be freely used by any person. In addition, the Conceptual Report states that this restriction shall include [...] 3) the rights and obligations of the municipality to register in the municipal street and road registry a road owned by another person as an engineering construction under possession and maintenance of the municipality; 4) the obligation of the municipality to carry out the necessary maintenance of the road if the road is registered in the municipal street and road registry and the NRECIS [24].

In this situation a new term is introduced the necessity for which is doubtful, but which will cause more problems. Establishing a new type of public access road or encumbrance "public road", it is possible that there will be problems with understanding and interpretation of the concepts and terms. Thus, when speaking about separate category of property encumbrance - "public road", people will understand it as the already existing designation "public road" for national or municipal roads. Article 2 Part two of the Law on Motor Roads states that "a motor road is a complex engineering construction outside city borders that is used for road traffic with fixed speed, load and size determined in the laws and regulations" [25]. But Part two states that "Complex of a motor road includes: bedding, road, artificial constructions (for example, bridges, overpasses, tunnels, trestle bridges, culverts, drainage systems, support walls), road engineering constructions (for example, bus stops and pavilions, speed lanes, parking lots, parking places, recreation areas, snow protection walls, greenery, bike lanes and pathways, road communication and lighting lines) and technical means for traffic organisation (for example, road signs, traffic lights, signal poles, protective barriers, vertical and horizontal marks) [25].

Having assessed the proposal provided in the Conceptual Report that the municipalities should be granted the rights and obligations to register in the municipal street and road registry a road owned by another person as an engineering construction under possession and maintenance of the municipality, we have to mention that this solution would lead to breach of the principle provided in Article 968 of the Civil Law "A building erected on land and firmly attached to it shall be recognised as part thereof" $[26,968]$. We have to note that 
this principle is not only applicable to buildings, but also to engineering constructions. J. Rozenfelds writes "physical integrity of a property means the legal restrictions for horizontal division of property or property fragmentation that ensures physical integrity of a property under ground and in the air space above the property, or the so called ad caelum. [...] During drawing up of the Civil Law in the 1930ies integrity of a property was very important thus emphasising that the Civil Law follows the general codification trends [...]. The requirement for physical integrity of a property is related to the regulation that any buildings and other constructions that are inseparably connected with the land are a part of it (superficies solo cedit). This connection is expressed in the way that ad caleum, which determines the sovereign power of the owner over the air and underground space could not exist, if at the same time there would be any separate property rights to any objects inseparably connected to that land." [27]

The Article 2 of the Law on Motor Roads cited above states that a road is an engineering construction closely connected with the bedding. Therefore it is recognised as a part of land. Of course, there always can be exceptions to the laws and regulations, as proposed by the authors of the Conception. Support to this solution will cause formation of shared property relations, where the land is owned by one owner, but the buildings by another. However, in period when the legal system of Latvia undergoes modernisation related to attempts to give up shared property [for example, see J. Dinsberga, I. Tiesniece (2016)], accepting of this solution would be irrational and unacceptable.

In the conclusion of the present article the authors would like to go back to the issue mentioned when evaluating the Conceptual Report with the data provided in Table 1. Since the Conceptual Report and the proposals therein are based on analysis of situation of only one municipality, there is a risk that problems of other municipalities have not been surveyed. Also there is no information of the situations that are in majority or minority in Latvia in general. The Conceptual Report states that the Ministry of Environmental Protection and Regional Development carried out survey of only 11 [28] municipalities regarding the criteria for establishment of public roads. During the survey the municipalities provided their opinion on solving of this problem, but it was not based on analysis of the actual situation of the particular municipality, which in its turn would be based on precise data. When adopting a decision of national importance and selecting a particular problem solution we cannot base on assumptions and incomplete situation analysis. The authors are of the opinion that each municipality of Latvia should carry out evaluation of the actual situation in their administrative territory, analyse the obtained data (on basis of single guidelines for data analysis) and draw up solutions for the problem situations. Each municipality after collection and analysis of data would be able to give concrete and not provisional assessment of the possible solutions taking into account the possibilities and human resources of the municipality. But the Ministry of Environmental Protection and Regional Development would carry out gathering of all data submitted by the municipalities, as well as aggregation and analysis of the solutions. It would allow understanding of the situation in Latvia in general and identifying the priority issues.

It is possible that finding of one solution suitable for all situations will be difficult. The results of the current study already show that each situation is individual and requires individual solutions. Therefore we have to agree with the opinion of the authors of the Conceptual Report that: "Considering the different points of view of the municipalities regarding the criteria for establishment of public roads, the competence of the municipalities to plan their administrative territory and to choose the most suitable criteria for establishment of public roads should be retained" [28]. The possible criteria, of course, should be drawn up and accepted by all municipalities, but each municipality would be able to choose the most suitable one.

Having conducted the research, the author states that: 
1) The purpose of the servitude of right of way is to benefit the dominant immovable property. However, now there are many servitudes of right of way which do not fulfil their purpose in Latvia. Moreover, there is no regulation how to eliminate such imperfections.

2) Stability and efficiency of the legal base in the field of ownership rights in Latvia is endangered because of both the problems caused by the enactments regulating the land reform and the influence of globalisation. Because the legislators are unable to adjust and adapt quickly the legal system to fast development of economic, social, technological and political processes and to elimination of the past mistakes.

3) Despite the fact that the problems related to the servitudes of right of way, established during the land reform, could be detected and even eliminated at the beginning of the land reform, the process of solving the problems on the state level began only at the end of the reform.

4) The Conceptual Report provides several solutions for the detected problem, however, the negative risks are mentioned as well, which, in author's opinion, endangers further implementation of the Conception.

5) Survey of the problems with servitudes of right of way, established by administrative acts, included in the Conceptual Report and selection of the possible solution is based on generalised data that do not reflect the situation in Latvia.

6) Term "public road" does not have an unequivocal description in the laws and regulations of Latvia and introduction of another term for the servitude of right of way established by administrative act cannot be allowed. It is doubtful that the direction provided in the Conceptual Report to introduce a new encumbrance of immovable property "public road" would give the desired effect.

\section{Conclusions}

1) While developing policy planning documentation and regulatory enactments for elimination of problems caused by the servitudes of right of way established during the land reform, the legislators should: (a) analyse whether the developed regulation will allow achieving the legislative aim mentioned in the legal provision; (b) refer to general legal principles. The author considers that the legislator's decision would be against justice and good faith if the servitude of right of way was determined as common use way only because it is faster and cheaper than alienation of immovable property for the needs of society; c) take into consideration the interests of the property owner, avoiding delegation to immovable property owners the responsibility for mistakes made by the state institutions in the past; d) when choosing the direction of the solution we have to take into account the principle of integrity of land and buildings (including engineering constructions) stipulated in Article 968 of the Civil Law.

2) The Directive 2014/47/EU of the European Parliament and of the Council on the technical roadside inspection of the roadworthiness of commercial vehicles circulating in the Union and repealing Directive 2000/30/EC Text with EEA relevance states that "public road" includes roads of various categories used by public. Establishing a new type of public access road or encumbrance "public road", it is possible that there will be problems with understanding and interpretation of these concepts and terms. Moreover, it would lead to breach of the principle of integrity of land and buildings provided in Article 968 of the Civil Law. 
3) The current study of the situation in one municipality of Latvia in relation to servitudes established during the land reform only gives an insight into the problem, but does not reflect the actual situation in Latvia. Should the decision on solving of the problems related to servitudes of right of way established by administrative acts be based on these insufficient facts, the history might repeat and decisions that are unreasoned and inadequate for the local situation might be passed. Therefore the authors provide the following proposals:

- Ministry of Environmental Protection and Regional Development shall charge all municipalities of Latvia to carry out study of the current situation, gathering and analysis of data, and to submit the obtained results to the ministry within the provided term;

- Ministry of Environmental Protection and Regional Development shall carry out aggregation and analysis of the all data and solutions submitted by the municipalities; draw up several courses of action and unified criteria, from which the municipalities will chose the respective course of action for solution of the particular problem, draw up respective drafts of laws and regulations based on the selected courses of action;

- grant all municipalities the right to choose the most appropriate course of action for solution of their problem situations.

\section{References}

1. The Convention for the Protection of Human Rights and Fundamental Freedoms. (1950) Protocol No. 1: international document. Latvijas Vēstnesis No. 143/144 (858/859), 13.06.1997

2. The Constitution of the Republic of Latvia. (1922) Article 105: Law of the Republic of Latvia. Latvijas Vēstnesis No. 43, 01.07.1993

3. The Civil Law (1937.): Law of the Republic of Latvia. Valdības Vēstnesis No. 44, 24.02.1937

4. $\quad$ Grūtups, A. Tiesu prakse un komentāri. Riga, Mans Īpašums (1994)

5. Conceptual Report On the Problems Occurring in Relation with the Servitudes of Right of Way Established during the Land Reform and Their Possible Solutions.

Available at: http://www varam.gov. lv/lat/lidzd/

attistibas_planosanas_dokumentu_projekti $/$ [viewed on

13.03.2017]

6. Dinsberga, J. Servitūti un ar to nodibināšanu saistītās problēmas. LPA Raksti 10 (2003)

7. Dinsberga, J. Ar ceḷa servitūta nodibināšanu saistītā problemātika. Available at: http: / /WWW. rsu. lv/studentiem/382-juridiska-fakultate/ 6296-macibu-konference-par-tiesisko-problemu-aktualiemjautajumiem [viewed on 02.01.2017]

8. Collection of Local Laws. Available at: fi le:///D: /Document/2006_ elektroniski_spriedumi_gramatas_likumi/Vietejo\%20civilli kumu\%2 0kopojums. II I dala. 1928.g. pd f [viewed on 13.03.2017]

9. Auders, M. Zemes reformas laikā ar administratīvo aktu nodibinātie ceļu servitūti. Available at: http://www varam.gov. lv/in_site/ tools/download.php?file=files/text/Seminari/tap//5_cela_ servituti_pascaron_valdibam_281114.pdf [viewed on 28.11.2016] 
10. Conceptual Report On the Problems Occurring in Relation with the Servitudes of Right of Way Established during the Land Reform and Their Possible Solutions.

Available at: http://WWW varam.gov. lv/lat/lidzd/

attistibas_planosanas_dokumentu_projekti/ [viewed on 13.03.2017]

11. Law on Administrative Territories and Populated Areas (2008) Attachments No. 1 and No. 2: Law of the Republic of Latvia. Latvijas Vēstnesis No. 202, 30.12.2008

12. Conceptual Report On the Problems Occurring in Relation with the Servitudes of Right of Way Established during the Land Reform and Their Possible Solutions.

Available at: http://WWW . varam.gov. lv/lat/lidzd/

attistibas_planosanas_dokumentu_projekti/[viewed on 13.03.2017]

13. Decision of the Supreme Council of the Republic of Latvia On Agrarian reform of the Republic of Latvia (1990): Legislative document of the Republic of Latvia. Zinotājs, 29, 19.07.1990

14. Law on Land Use and Land Survey (1991): Law of the Republic of Latvia. Ziņotājs No. 31/32, 15.08.1991. (Expired: 30.12.2009)

15. Regulations of Rural Area Land (1991): Resolution of the Council of Ministers of the Republic of Latvia. Zinotājs No. 10, 05.03.1992

16. Grūtups, A. Tiesu prakse un komentāri. Riga, Mans Īpašums (1994)

17. Cabinet of Ministers Meeting Protocol, Conceptual Report On the Problems Occurring in Relation with the Servitudes of Right of Way Established during the Land Reform and Their Possible Solutions (2013): Latvijas Vēstnesis No. 216, 05.11 .2013

18. Regulations for Territory Use and Construction of the Town of Valdemārpils with its Rural Territory. Available at: www valdemarpils. lv/file.php? id=17 [viewed on 26.11.2016]

19. Territory Planning of Roja District (2011 - 2023): Regulations for Territory Use and Construction of Roja (2011). Available at: file:///D: Downloads/Rojas\%20AN, pdf [viewed on 26.11.2016]

20. Regulations for Territory Use and Construction of Jēkabpils (2010). Available at: www.jekabpils.lv/sites/default/files/universalais/2013/01/1023.../apbuve2010.doc [viewed on 26.11.2016]

21. Law on Expropriation of the Public Person Property (2002): Law of the Republic of Latvia. Latvijas Vēstnesis No. 168 (2743), 19.11.2002

22. Directive 2014/47/EU of the European Parliament and of the Council of 3 April 2014 on the technical roadside inspection of the roadworthiness of commercial vehicles circulating in the Union and repealing Directive 2000/30/EC (Text with EEA relevance): OJ L 127, 29.4.2014, p. 134-218

23. Road Traffic Law (1992): Law of the Republic of Latvia. Ziṇotājs No. 13/14, 02.04.1992

24. Conceptual Report On the Problems Occurring in Relation with the Servitudes of Right of Way Established during the Land Reform and Their Possible Solutions.

Available at: ht tp://wWw . varam.gov. lv/lat/lidzd/ attistibas_planosanas_dokumentu_projekti $/$ [viewed on 13.03.2017]

25. Road Traffic Law (1992): Law of the Republic of Latvia. Ziṇotājs No. 13/14, 02.04 .1992

26. The Civil Law (1937.) Article 968: Law of the Republic of Latvia. Valdības Vēstnesis No. 44, 24.02.1937 
27. Rozenfelds, J. İpašuma fiziskās vienotības (ad caelum) entropija Latvijas tiesībās. Jurista Vārds. 51 (750) (2012)

28. Conceptual Report On the Problems Occurring in Relation with the Servitudes of Right of Way Established during the Land Reform and Their Possible Solutions. Available at: http://WwW varam.gov. lv/lat/lidzd/ attistibas_planosanas_dokumentu_projekti $/$ [viewed on 13.03.2017]

29. Dinsberga, J., Tiesniece. I. Problems Related to the Abolition of Divided Real Estate Ownership (2016). Available at: https://Www degruyter . com/ view/j/jec.2016.13.issue-2/jec-2016-0021/ jec-2016-0021.xml [viewed on 12.03.2017] 
